\title{
INTRODUCTION TO SOCIOLOGY. XVI
}

\author{
PART III. GENERAL STRUCTURE OF SOCIETY \\ CHAPTER VII. THE SOCIAL FRONTIERS (CONTINUED) \\ SECTION VII. GAUL AND GERMANY - THE CHRISTIAN CHURCH \\ G. DE GREEF \\ Rector of the Nouvelle Université, Brussels, Belgium
}

In his Atlas of Historical Geography M. F. Schrader says:

The limits of Italy often changed in antiquity. .... We see that the Romans never regarded the Alps as the natural and necessary frontier of Italy. In their eyes the Alps were only the geographical boundary of that country; the political limits were always traced either to the south or to the north of the range.

This observation is perfectly correct, although vague; after all that we have already pointed out, it would have been more exact if the author had concluded that there are no natural frontiers, but only social frontiers; then only are explained the continuous changes of frontiers, not only of ancient Italy, but of the Italy of the Middle Ages and of modern times as well, and even of those of all other societies, whether political or not.

In order to protect Italy and communicate with Spain, it was necessary to conquer Gaul. Likewise in order to make sure of Gaul, it would have been necessary to advance beyond the Rhine into Germany. There was, moreover, a further necessity imposed upon society, which was to procure through conquest the possibility of the continuous economic exploitation of the population of new territories. It was not exactly commercial outlets which Rome sought to create as do modern states, but rather to draw upon the labor and wealth of other peoples. The rigid law of property which she had established for the interior extended in a vaster form, through her domination, to the exterior.

We have here, however, to concern ourselves only with the 
frontiers, and to seek the facts which may serve as the basis of a positive theory in regard to this main problem.

If we consult the works especially of G. de Mortillat upon prehistoric France and the formation of the French nation, and other works not less remarkable, and put them in relation with geographical facts, we observe, in the age of reindeer and of caves, the well-established existence of more than five hundred caverns scattered through half a hundred of the present departments of France. These caverns are in general distributed along, and on either side of, water-courses, streams, or rivers. Therefore, even at this remote period, water-courses, which were doubtless followed imperceptibly from source to mouth, no longer constituted, if they had ever done so, natural barriers or frontiers.

The same observation is applicable to the age of polished stone, characterized by megalithic monuments, dolmens, etc. The area of the megalithic monuments extends almost without interruption from the beaches of Norway and Sweden along the coast of western Europe to the shores of Morocco, Algeria, and Tunis; it follows the Rhone and the Saone upon either side, thence turns toward the east, through Chalons to Berlin. Outside of this extensive zone, embracing a uniform civilization, one does not find a trace of it; but, whatever its inner subdivision into distinct groups, one perceives that this civilization was already both fluvial and littoral. According to Alexander Bertrand, it reappeared on the one side as far away as the foot of the Caucasus, and on the other, in Lencoran in Transcaucasia.

All these cave and megalithic populations were subdued by the Celts, and they were, moreover, distinct from the Ligurians, whose area of expansion was almost entirely outside of the limit of the regions occupied by the megalithic populations.

Another Indo-European current was oriental. Starting from the Black Sea and the valleys of the Caucasus, or the great plains of the Don and the Volga, it followed the banks of the Danube and the Dneiper. It established the lacustrine cities in the Swiss lakes, and as far as Lake Bourget in Savoy, as well as in those of the valleys of the Danube, always indifferently upon both banks; and also in northern Italy. 
According to d'Arbois de Jubanville, the oldest Celtic settlements were to the East of the middle Rhine in the basin of the Main and upon both banks of the upper Danube. Toward the end of the seventh century before our era, too cramped for room, or driven back by other tribes, they divided into two groups. The one, turning toward the North Sea, occupied the northern plains of Germany and the British Isles; the other crossed the Rhine and established itself between the Atlantic Ocean and the Alps, spreading later into Spain, where it dominated from the sixth century until the Carthaginian conquest effected between the years 236 and 218. All of these Celtic populations thus spread by following river basins and natural highways, and, when necessary, by crossing mountains. It was impossible to confine them between rivers or mountains; they even crossed the sea.

The Alps even were surmounted; the Celtic invasion of Italy was quickly followed by the taking of Rome by the Gauls in 390. Some established themselves in the valley of the Po; the others, toward the southeast in the region between the Appennines and the Adriatic. At the same time, other tribes occupied Pannonia and northern Thrace. The Celtic race touched the Black Sea, and thence spread into Galatia in Asia Minor. In Europe, just as in Asia, this civilization was essentially fluvial and continental, and in reality interfluvial. Other movements, of settlements, of repulse, and of replacement, were produced in succession at the same time with regional differentiations. Thus the Belgæ, driven out of Germany, settled from the Rhine to the Seine; others established themselves in the center of Gaul. The Belgæ also crossed the Channel and colonized Britain. As to the Ligurians, who occupied the whole basin of the Rhone and the upper portions of the Garonne and of the Seine, they were forced back toward the Mediterranean. All the divisions and subdivisions which were produced in the mass of the Celtic populations were social combinations, of which the mountains and the rivers were only accessory elements and by no means decisive.

At the coming of Cæsar, Gaul extended on the south to the middle and lower basin of the Garonne (it should be observed that it occupied both banks). On the east it touched and pene- 
trated the Cevennes, and extended as far as the upper course of the Rhone; and, if it stopped at this river, it was because behind it was the Roman province, which was a social force. It included a part of Switzerland with its mountains and the upper course of the Rhine. From this point the Rhine served as its boundary, but was continually crossed in both directions. Gaul thus embraced a great number of fluvial basins: the Garonne, the Loire, the Seine, the Scheldt, the Meuse; and many orographic systems besides. It touched upon the Atlantic and the North Sea, and it crossed the Channel.

It would, however, be an error to consider Gaul as forming what we call a nationality. It was divided into tribes, which formed alliances and federations, following circumstances in a more or less permanent fashion, and which were divided among themselves by divergent social interests exploited by the ambition of the chiefs.

It is here necessary only to keep in mind that all the tribes occupied portions of basins; they were thus geographically interdependent; they were separated neither by rivers nor by mountains. This will prove to be a factor favorable to their fusion.

A number of years before our era, under Augustus, we find Gaul divided into three provinces - Belgic Gaul, Celtic Gaul, and Aquitaine. All the old territorial limits of the tribes or groups of tribes, already so slightly geographic, were overthrown. The Celtic province had henceforth only half of its old territory; that of Aquitaine was quintupled, including all the country between the Loire and the Garonne. In return, two Belgian civitates were annexed to the Celtic province, and three Celtic civitates to the Belgic. Even the number of civitates changed; from the year Io B. C. to $20 \mathrm{~A}$. D. the number increased from 60 to 64 . Toward the year 400, Gaul included not less than I7 provinces and I I 3 cities. Both had become simple administrative, financial, and military divisions. As to the two parts of Germany, they were both independent of the Belgic province from a military point of view, and dependent from a civil and financial point of view. There can therefore be no question in regard to the natural frontiers of the tribes; for, supposing that there had been such, they 
had disappeared, and there can no longer be any question regarding the supposed natural frontiers of Gaul, since it was included within the Roman Empire. What, then, are these pretended natural frontiers which never are frontiers?

In Gaul all the traditional forms of the tribes were overthrown at the point where we see the name of the chief generally substituted for that of the civitas. On the contrary, in the three Gauls we see the principal place take the name of the civitas; thus Luteteia was called Parisii.

Gaul was only a geographical expression; Galates and Gauls are Celts; they are the successive names of the same population. They crossed over the Pyrenees, and toward the northeast extended, by way of the valley of the Danube, as far as the Scythians, with whom they mixed at their extremities, and formed the Celtoscythians. All the consecutive divisions and differentiations of the Celts are purely sociological divisions and differentiations; that is to say, they are more complex than those which are only physical. The Germans themselves appear to have been only Celts or Gauls whose type was preserved in its purity for a longer time.

Less advanced in civilization than their brothers in Gaul proper, the Germans, according to Tacitus, still lived separately and dispersed, in discontiguous village settlements, surrounded by unoccupied territory. The lands were occupied by all the tribes successively, and in proportion to the number of cultivators; they were distributed according to the rank of each. The vast extent of their plains facilitated these divisions. They changed their pieces of ground each year, and there was always free land; they did not, therefore, need to take account of the fertility and the extent of their lands. They raised only wheat; they seem neither to have planted vineyards nor to have inclosed meadows. They were at once hunting, pastoral, and agricultural tribes, partly sedentary and partly migratory. According to Tacitus, ${ }^{1}$ these populations were held within natural — that is to say, physical-limits: the Rhine, the Danube, the mountains, the ocean. But Tacitus recognized that the Cimbri, having set out from Jutland, encamped simultaneously upon both banks of the Rhine,

${ }^{1}$ Germania, I, xvi, xx. 
where they left "vast remains of their camps and their inclosures." As to the Teutons and the Suevi, Marius and Cæsar were obliged to drive them out of Gaul, whither they had penetrated. Belgic Gaul included also populations considered Germanic.

Among the ancient Germans the tribe was still the fundamental force of society. Each of them dwelt within limits which were not physical, but fixed by agreement either previous to or after conflict. The German mark was a territory held in possession by a colony formed in primitive times of a family, or a larger or smaller related group. German colonization was effected through the creation of successive marches, which, even when German expansion had been carried very far, long preserved the character which we have already met with in the case of all marches whatsoever. In the mark each free member of the community had a right to the enjoyment of the forests, pastures, and arable land; this was only a right of usufruct or of possession. After each harvest, the plot of ground returned to the common holdings, and the German remained the permanent possessor of only the land upon which he dwelt, with its immediate surroundings. The Germans were also unacquainted with wills, although they permitted inheritance, in so far as the holding was considered the property of each head of a family. Inheritance took place in the following order: first, children; second, brothers; third, paternal and maternal uncles.

When the population of the mark became excessive, emigration and the formation of a new mark occurred. The same phenomenon was produced almost simultaneously in all the ancient marks, the emigrants forming enormous bands which searched for lands and wealth in the most distant countries beyond rivers and mountains. All the German marks adhered to this social organization. The Teutonic Mark was formed by a primitive establishment of a group of related persons among whom, as Cæsar said of the Suevi, the land was distributed inter gentes et cognationes hominum.

The marks most recently formed, those which were the most distant from the primitive marks and which found themselves at the extremities of the German possessions, upon the frontiers, 
were naturally the most warlike; and still more was this true of the bands which set out en masse at random. We also see that always, or almost always, the military marches became the centers for the formation of great military states, and indeed of the greater part of those which constitute the great powers of modern Europe.

Such are the general laws of development of societies whose type is, in whole or in part, the Mark-Genossenschaft, and the allmend or ordinary mark of the Germans. This presents the strongest analogies with the primitive forms of populations which have not been in relation with Germany; for example, those found among the American tribes. However, these latter have in general a less evolved economic structure. Thus, while the Germans pastured their cattle in the mark, and had even established certain rules for the exploitation of the forests, and had distinguished a sort of private property from the common ownership, the Indian tribes, still in the hunting stage, recognized only common property, with the exception of certain movable objects. Already the German custom approached more nearly the Greek stage, where the free man was proprietor of his piece of ground, with a right of inheritance in favor of his family. But in Greece and among the American Indians, as well as among the Gauls and the Germans, the communistic forms reappeared regularly with greater or less distinctiveness in military colonization. The military, hunting, pastoral, or agricultural colony tended everywhere and always to reproduce the communistic type with its military accessories. The mark, whenever it has an economic form in military societies, is the most characteristic in the military marches, upon the extreme frontiers, while in the original centers this character tends to become more complex and to give birth to a peaceful development. In the interior the social development tends to become more and more differentiated from the military structure, whose force, on the other hand, increases in proportion as we approach the frontier.

The evolution, for example, of the possession of the soil, in spite of accessory variations, has followed almost everywhere an identical direction; namely: (I) right of possession of the 
horde; (2) right of possession of the tribe; (3) right of possession of the clan; (4) right of possession of a family of the clan. Now, it is always on the frontiers of each civilization that the most simple forms are found; they are at the limits of the social space as they are at those of time.

When one observes that the lex Salica and the Saxenspiegel of the Germans reveal a customary right corresponding to the traditional usages of the American tribes, it is evident that these fundamental resemblances cannot be explained by imitation; and as it is true of possession and ownership, it is equally so in the case of the frontiers which are the external form of the combination of a population and a fixed territory - a combination out of which a society results.

Everywhere for genetic social structures with their corresponding frontiers we see substituted, under similar conditions, divisions whose bases are no longer natural, in the sense of physical or genetic. The same evolution occurs at the same stages, with the same essential characters, as well in Asia, in America, and in Africa as in Europe, and as well among the Aryans as among the Semites, the yellow, black, or red-skinned races. It is no more astonishing to see the ancient Peruvian capital divided into separate and unalterable quarters, according to the places of origin of the population, than to learn that the military forces were actually stationed in general in distinct districts and buildings, and even that each arm had its special quarters. In the Middle Ages, and even later, there were such quarters for every occupation, and also for inhabitants of different origins, as even today the names of a great number of our streets recall.

As the regional and genetic divisions tend to disappear, we see appearing simply numerical divisions, which recall only remotely the structure of the clan and of the family. Thus, the Hebrews were grouped in tens, fifties, hundreds, and thousands. These same subdivisions are met with everywhere under analogous conditions. Thus in Japan, according to Alcock, ${ }^{2}$ in certain parts of the country there exists a sort of hierarchial system of chiefs of tens and of hundreds, the otonos of the towns and vil-

${ }^{2}$ The Capital of the Tycoon. 
lages. They are responsible individually and collectively for the good conduct of their groups. The fact is that these Japanese towns and villages had a structure which was no longer that of the tribe or the clan. Japan, at the time when the abovementioned author wrote, was in a situation analogous to that of our states of the Middle Ages, where we find the same kinds of division. Will anyone claim that Japan has imitated Europe of the Middle Ages? The most general conditions of the life of societies being everywhere the same, and the number of social combinations possible in view of adaptation to these conditions being limited, what wonder that the same forms are met with everywhere at the same stages? This is no more extraordinary than the homogeneity of the human species, or than the homogeneity of the evolution of each individual of this species. It is necessary to bear well in mind this leading sociological conception, that not only are all men of the same species, but that human societies are also all of the same species, in spite of their possible, but always limited and accessory, variations.

E. de Laveleye confirms the preceding observations relative to the simply arithmetical divisions which, at a certain moment, replace the genetic groupings, when he recalls, in La proprieté et ses formes primitives, that in former times in Russia

every member of the society must enter a group of ten (decanie), which had as its mission the defense or the guarantee of all in general and of each in particular; that is to say, it was the function of the group of ten to avenge the citizen who belonged to it, and to exact the wehrgeld, if he had been killed; but at the same time it went security for all its members.

If the division into groups of ten took the place of that into communities of clans or of tribes, it was evidently because the social frontiers had passed beyond those of the tribes and the clans whose structure was broken down. The inner social divisions are always correlated with the general structure of the society or of the state, and notably with that of its frontiers.

As to the Russian mir, it still exists, as in France before the Revolution of 1789 , and it still preserves certain village communities. The mir is in fact the village commune, formed by the descendants of the same family group of nomads who have 
become sedentary. It has a judicial existence; it is proprietor of the soil; its members enjoy only usufruct or temporary possession; it is governed by the heads of families assembled in council under the presidency of the starosta, or mayor, chosen by them.

The same groupings, with the same delimitations, are met with in all civilizations at the same stage - in Egypt, in China, in India, in Persia, among the Semites, and the Aryans, Celtic, German, and Slavic. This internal organization, in connection with the technique and the modes of economic circulation and production, always corresponds to an organization adequate to the general structure of the societies, and notably to the frontiers which separate them from other societies.

In England, in the early centuries, the hundred moot was the basis of the social organization, as the assembly for local government. Every free man under Canute II and Edward the Confessor must be a member of a hundred and of a tything. Ten similar gylds formed a hundred (Stubbs). Under the Frankish law there was the decanus and the centenarius. Under the Merovingians it was likewise obligatory that every free man should be present at the assemblies, especially of centuries; fines were imposed for absence. In time of war the Germanic peoples, when no other bond united them, formed in families, and in companies under chiefs. These German chiefs had their comites.

Thus, when new groupings are formed no longer tending to be genetic, these new internal divisions correspond naturally to a larger extension of the frontiers.

[To be continued] 